\title{
PERBUATAN MELAWAN HUKUM DALAM PERTANGGUNGJAWABAN DOKTER TERHADAP TINDAKAN MALPRAKTIK MEDIS
}

\author{
I Gusti Ayu Apsari Hadi \\ Jurusan Ilmu Hukum Universitas Pendidikan Ganesha \\ Email: apsari.hadi@gmail.com
}

\begin{abstract}
Abstrak
Tindakan malpraktik medis masih menjadi permasalahan dalam bidang kesehatan yang belum diatur dengan jelas dalam suatu perundang-undangan hukum nasional. Akan tetapi unsur-unsurnya sudah tertuang di dalam UU No. 36 Tahun 2009 tentang Kesehatan yang mencakup di dalamnya penegakan hukum pidana, administrasi dan hukum perdata. Dalam perspektif hukum perdata malpraktik medis merupakan tindakan perbuatan melawan hukum yang memenuhi ketentuan dalam Kitab Undang-Undang Hukum Perdata. Penelitian ini menggunakan penelitian yuridis normatif dengan bahan hukum primer dan sekunder. Hasil penelitian ini menunjukkan bahwa Gugatan perbuatan melawan hukum (onrechtmatige daad) dalam tindakan malpraktik medis diatur dalam Pasal 1365 BW dengan unsur-unsur : 1) Pasien harus mengalami suatu kerugian; 2) Ada kesalahan atau kelalaian (disamping perseorangan, rumah sakit juga bisa bertanggung jawab atas kesalahan atau kelalaian pegawainya); 3) Ada hubungan kausal antara kerugian dan kesalahan; 4) Perbuatan itu melanggar hukum. Selain itu bentuk pertanggungjawaban dalam perbuatan melawan hukum malpraktik medis berdasarkan pasal $1365 \mathrm{BW}$ ialah bisa berupa ganti rugi materi dan immateri yang haruslah terdapat hubungan yang erat antara kesalahan dan kerugian yang ditimbulkan.
\end{abstract}

Kata kunci: Perbuatan Melawan Hukum, Pertanggungjawaban, Malpraktik, Medis

\begin{abstract}
Medical malpractice remains a problem in health that has not been clearly regulated in a national legislation. But the elements are already contained in Act No. 36 of 2009 on Health which includes criminal law enforcement, administration and civil law. In the perspective of civil law a medical malpractice is an unlawful act conduct that complies with the provisions of The Civil Code. This research based on normative juridical method within primary dan secondary legal materials. The results of this study indicate that the lawsuit of unlawful act (onrechtamtige daad) in medical malpractice is regulated in Article 1365 of the Civil Code with elements : 1) the patient must experience a tort; 2) there are errors or missions (in addition to individuals, hospitals may have duty for errors or missions); 3) there are causal between tort and error; 4) The act is unlawful. In addition, the responsibility of the unlawful act against the medical malpractice ased on Article 1365 of the Civil Code is can be material and immaterial compensation that have a related between errors and torts.
\end{abstract}

Keywords: The Unlawful Act, Duty, Malpractice, Medical 


\section{A. PENDAHULUAN}

\section{Latar Belakang}

Kesehatan menjadi salah satu kebutuhan penting dalam menunjang kehidupan masyarakat. Tanpa kesehatan tentunya seseorang tidak akan bisa melaksanakan aktivitasnya dengan prima. Sebagai suatu kebutuhan mendasar, kesehatan menjadi hak bagi setiap individu (the right of self determination) yang harus diwujudkan dalam bentuk pemberian kesehatan yang aman, berkualitas, dan terjangkau oleh masyarakat. ${ }^{1}$ Hukum memegang peranan penting dalam mewujudkan bentuk pemberian kesehatan tersebut dan mengoptimalkan derajat kesehatan masyarakat.

Oleh karenanya, semenjak diatur dalam UU No. 23 Tahun 1992 yang kemudian diubah dengan UU No. 36 Tahun 2009 tentang Kesehatan, Pasal 2 menyatakan bahwa setiap kegiatan dan upaya untuk meningkatkan derajat kesehatan masyarakat harus dilaksanakan berazaskan perikemanusiaan, keseimbangan, manfaat, perlindungan, penghormatan terhadap hak dan kewajiban, keadilan, gender dan non diskriminatif serta norma-norma agama.

UU No. 36 Tahun 2009 merupakan upaya pemerintah dalam mewujudkan suatu pelayanan kesehatan yang lebih baik bagi masyarakat. Seiring dengan tingkat kesadaran masyarakat yang tinggi akan pelayanan kesehatan, para pihak yang melakukan pelayanan kesehatan dalam hal ini tenaga medis dan rumah sakit dituntut untuk turut serta meningkatkan pelayanan kesehatan yang optimal bagi masyarakat. Akan tetapi tidaklah mudah dalam mewujudkan suatu pelayanan kesehatan tanpa disertai dengan standar pelayanan operasional (Standard Operating Procedure) dengan memperhatikan setiap hak dan kewajiban pasien

Menurut Hodgetts dan Casscio, pelayanan kesehatan disebutkan pelayanan kedokteran (medical service) dan pelayanan kesehatan (public health service). Leavel dan Clark berpendapat bahwa kedua macam pelayanan kesehatan tersebut mempunyai ciri masing-masing; pelayanan kesehatan pada umumnya diselenggarakan bersama-sama dalam satu organisasi serta mengikutsertakan masyarakat; adapun pelayanan kedokteran dapat diselenggarakan sendiri dengan

1 Riska Andi Fitriono, Budi Setyanto dan Rehnalemken Ginting, "Penegakan Hukum Malpraktik Melalui Pendekatan Mediasi Penal", Yustisia, Vol. 5 No. 1 Tahun 2016, hlm. 87. 
tujuan utamanya mengobati (kuratif) dan memulihkan (rehabilitatif) serta sasaran utamanya adalah perorangan. $^{2}$

Pelayanan kedokteran yang bertujuan utama tidak hanya secara kuratif maupun rehabilitatif merupakan salah satu kewajiban dokter dalam melaksanakan praktik kedokteran sesuai dengan UU No. 29 Tahun 2004 Tentang Praktik Kedokteran. Dalam ketentuan Pasal 51 UU No. 29/2004 dokter atau dokter gigi dalam melaksanakan praktik kedokteran mempunyai kewajiban: a. memberikan pelayanan medis sesuai dengan standar profesi dan standar prosedur operasional serta kebutuhan medis pasien; b. merujuk pasien ke dokter atau dokter gigi lain yang mempunyai keahlian atau kemampuan yang lebih baik, apabila tidak mampu melakukan suatu pemeriksaan atau pengobatan; c. merahasiakan segala sesuatu yang diketahuinya tentang pasien, bahkan juga setelah pasien itu meninggal dunia; d. melakukan pertolongan darurat atas dasar perikemanusiaan, kecuali bila ia yakin ada orang lain yang bertugas dan mampu melakukannya; dan e. menambah ilmu pengetahuan dan mengikuti perkembangan ilmu kedokteran atau kedokteran gigi.

Awalnya hubungan antara dokter dan pasien dikenal bersifat paternalistik, yakni hubungan di mana pasien yang dibolehkan hanyalah patuh secara mutlak kepada sang pengobat. Akan tetapi, pada saat ini terdapat pergeseran paradigma dalam hubungan interpersonal yang sebelumnya berdasarkan pola hubungan vertikal paternalistik menjadi pola hubungan horizontal kontaktual. Dengan ini, segala tindakan medik yang akan dilakukan dokter terhadap pasiennya harus mendapat persetujuan pasien, setelah pasien mendapat penjelasan tentang penyakit dan upaya tindakan mediknya.

Mengenai tindakan medik yang dilakukan oleh dokter, senantiasa akan mengakibatkan dua kemungkinan yaitu berhasil dan tidak berhasil. Ketidakberhasilan bisa disebabkan oleh dua hal, pertama disebabkan oleh overmacht (keadaan memaksa), dan kedua disebabkan karena dokter melakukan tindakan medik yang tidak sesuai dengan standar profesi medik atau bisa dikatakan karena kelalaian.

2 Moh. Hatta, Hukum Kesehatan dan Sengketa Medik, Yogyakarta: Liberty, 2013, hlm. 120. 
Adanya kelalaian menjadi salah satu unsur tindakan malpraktik medis yang sangat umum. Malpraktik sendiri memiliki makna harfiah, kegagalan melakukan tugas. Kegagalan ini dapat disebabkan berbagai macam faktor : ${ }^{3}$

a. Adanya unsur kelalaian.

Kelalaian adalah sikap kurang hati-hati, melakukan tugasnya dengan tidak hati-hati atau tidak sewajarnya. Tetapi dapat pula diartikan dengan memberikan tindakan di bawah standar pelayanan medik.

b. Adanya unsur kesalahan bertindak.

Kesalahan bertindak ini terjadi karena kurangnya ketelitian dokter di dalam melakukan observasi terhadap pasien sehingga terjadilah hal yang tidak diinginkan bersama.

c. Adanya unsur pelanggaran kaidah profesi ataupun hukum.

Pelanggaran kaidah profesi ini terjadi pada saat seorang dokter atau petugas kesehatan melakukan tindakan di luar batas wewenangnya.

d. Adanya kesengajaan untuk melakukan tindakan yang merugikan.

Tindakan kesengajaan terjadi ketika seorang dokter atau petugas kesehatan lainnya melakukan hal-hal di luar apa yang seharusnya dilakukan hanya karena alasan untuk memperoleh keuntungan semata.

Dengan demikian malpraktik dapat diartikan sebagai suatu kelalaian ataupun kesalahan bertindak yang dilakukan oleh dokter dalam mempergunakan keterampilan dan ilmu pengetahuan yang lazim dipergunakan untuk mengobati pasien. Penyelesaian masalah malpraktik medis seringkali ditempuh melalui jalur litigasi, baik pidana maupun perdata. Baik dalam pidana maupun perdata pertanggungjawaban dokter dapat dikenakan sanksi yang sifatnya pidana maupun perdata maupun administratif.

Dalam tulisan ini akan memfokuskan pada aspek hukum perdata dalam tindakan malpraktik medis.

3 Alexandra Indriyanti Dewi, Etika dan Hukum Kesehatan, Yogyakarta: Pustaka Book Publisher, 2008, hlm. 266. 


\section{Rumusan Masalah}

Bagaimana suatu tindakan dokter memenuhi unsur perbuatan melawan hukum dalam malpraktik medis dan bagaimana pertanggungjawaban dokter dalam tindakan malpraktik medis dilihat dari perspektif hukum perdata?

\section{B. PEMBAHASAN}

\section{Tindakan Dokter Memenuhi Unsur Perbuatan Melawan Hukum dalam Malpraktik Medis}

Malpraktik merupakan istilah yang sangat umum sifatnya dan tidak selalu berkonotasi yuridis. Malpraktik dalam Kamus Besar Bahasa Indonesia adalah istilah untuk dunia kedokteran yang berasal dari kata "mal" atau "mala" yang artinya buruk, sedangkan praktik artinya pelaksanaan pekerjaan. Berdasarkan Black's Law Dictionary, "Malpractice is an instance of negligence on incompetence on the part of professional". ${ }^{4}$ Jadi dapat diartikan dalam terjemahan bebas, malpraktik adalah kelalaian yang merupakan bagian dari ketidakkompetenan sebuah profesionalitas.

Dalam dunia kedokteran seringkali suatu kesalahan kecil dapat menimbulkan akibat berupa kerugian besar khususnya bagi pasien. Pada umumnya pasien tidak dapat membedakan mana yang merupakan perbuatan pelanggaran etik dan mana yang dikategorikan perbuatan melawan hukum. Pada prinsipnya, pelanggaran etik belum tentu merupakan malpraktik, sedangkan malpraktik sudah barang tentu merupakan pelanggaran kode etik profesi medis.

Berkaitan dengan pelanggaran kode etik maka di dalam hukum kesehatan terdapat beberapa teori etika yang dapat digunakan sebagai landasan pertimbangan guna mengambil suatu keputusan pelanggaran kode etik bagi profesi medis. Ada dua macam teori etika yang dikenal luas pada aspek kesehatan: ${ }^{5}$

1. Teori Etika Klasik.

Salah satu teori dalam etika klasik yakni taleologis. Teori ini memberikan landasan bahwa benar tidaknya suatu tindakan tergantung dari akibat-akibat yang dihasilkan. Sebagai contoh dalam tindakan aborsi, menurut pendekatan taleologis aborsi dapat dibenarkan apabila alasan yang digunakan memadai 
dan tujuannya benar-benar untuk menyelamatkan kehidupan si ibu. Jadi apabila suatu perbuatan bermanfaat atau memiliki berakibat baik maka boleh dilakukan. Hanya saja tujuan atau manfaat bagi beberapa orang bisa menimbulkan ketidakadilan bagi sebagian orang.

2. Teori Etika Nilai.

Etika nilai menyatakan bahwa nilai ditentukannya sebagai suatu kualitas material, suatu sifat berisi. Nilai itu tidak ada tetapi berlaku dan tidak dapat dikembalikan pada unsur-unsur empiris manusia. Terdapat beberapa tolok ukur yang dapat digunakan sebagai ukuran etika nilai yakni nilai kejujuran, nilai otentik. Nilai otentik dapat diartikan sebagai "asli" atau menjadi diri sendiri. Manusia otentik adalah manusia yang menghayati dan menunjukkan diri sesuai dengan keaslian dan kepribadiannya. Dapat dicontohkan, seorang dokter menjadi spesialis diharapkan karena orang tersebut mencintai profesinya, menghargai nilai manusia dalam profesinya dan bercita-cita mengabdikan hidupnya untuk profesinya. Dengan demikian profesinya sebagai dokter otentik dengan kepribadian orang tersebut.

3. Teori Etika Kontemporer.

Etika kontemporer berkaitan dengan dasar pengambilan keputusan etis dalam permasalahan pengobatan modern. Budi pekerti yang luhur tercakup di dalamnya karena setiap tindakan yang dilakukan harus mencerminkan budi pekerti yang luhur dari setiap paramedis.

Setiap tindakan pelanggaran kode etik dokter akan senantiasa berkaitan dengan nilai-nilai etika dalam penyelesaiannya. Terkadang perbedaan pandangan dalam membuat suatu keputusan etis disebabkan tindakan medis tidak hanya didasarkan kewajiban tetapi juga moral yang bertentangan. Sehingga peran lembaga-lembaga etika kedokteran juga diperlukan dalam penyelesaian permasalahan-permasalahan pelanggaran etik.

Ada kalanya permasalahan etik tindakan dokter dibawa ke ranah yuridis jika perbuatan tersebut dikategorikan perbuatan melawan hukum. Jika dilihat istilah perbuatan melawan hukum menuru para ahli adalah, diantaranya : R. Wirjono Prodjokoro menggunakan Perbuatan Melanggar Hukum, Utrecht memakai istilah Perbuatan yang bertentangan dengan asas-asas hukum. Menurut R. Wirjono Prodjodikoro, "perbuatan melanggar hukum adalah agak sempit, karena yang 
dimaksudkan dengan istilah ini tidak haya perbuatan yang langsung melanggar hukum, melainkan juga perbuatan yang secara langsung melanggar peraturan lain daripada hukum, akan tetapi dikatakan secara tidak langsung melanggar hukum". 6

Dilihat dari aspek hukum perdata, terdapat dua kemungkinan yang dapat dipakai untuk dijadikan sebagai dasar yuridis tindakan malpraktik medis. Pertama, Gugatan berdasarkan adanya wanprestasi terhadap suatu kontrak. Gugatan wanprestasi dalam ketentuan Kitab Undang-Undang Hukum Perdata (KUHPerdata/BW) tertuang dalam Pasal 1329 yang berbunyi, "Tiap-tiap perikatan untuk berbuat sesuatu atau, untuk tidak berbuat sesuatu, apakah si berhutang tidak memenuhi kewajibannya, mendapatkan penyelesaiannya dalam kewajiban memberikan pergantian biaya, rugi, dan bunga”.

Jadi menurut BW gugatan wanprestasi yang terjadi dalam hal gugatan malpraktik bisa diajukan karena adanya perjanjian terapeutik yang dilanggar. Perjanjian terapeutik merupakan hubungan antara dokter dan pasien yang tertuang dalam kesepakatan di antara keduanya yang mana pasien sebagai pihak yang minta bantuan untuk kesembuhan penyakitnya dan dokter sebagai pihak yang menyembuhkan. ${ }^{7}$ Perjanjiannya meliputi perjanjian tertulis maupun tidak tertulis asalkan syarat-syarat sahnya perjanjian sudah dipenuhi berdasarkan ketentuan Pasal $1320 \mathrm{BW}^{8}$

Kedua, gugatan yang didasari atas perbuatan melawan hukum. Gugatan perbuatan melawan hukum diatur dalam Pasal 1365 BW yang berbunyi, "Tiap perbuatan melawan hukum, yang membawa kerugian kepada seorang lain, mewajibkan orang yang karena salahnya menerbitkan kerugian itu, mengganti kerugian tersebut".

Perbuatan Melawan Hukum atau onrechmatigedaad diartikan bahwa salah satu pihak telah melakukan perbuatan melawan hukum karena tindakannya atau perbuatannya bertentangan dengan asas kepatutan, ketelitian serta sikap kehatihatian terutama dalam hal ini perjanjian atau kesepakatan antara pasien dengan

6 R. Setiawan, Tinjauan Elementer Perbuatan Melawan Hukum. Bandung: Alumni, 1982, hlm. 8 .

7 Moh. Hatta, Op.cit., hlm. 71.

$8 \quad$ R. Subekti \& R. Tjitrosudibio, Kitab Undang-Undang Hukum Perdata, Pasal 1320. Untuk sahnya suatu perjanjian diperlukan empat syarat:

1. Sepakat mereka yang mengikatkan dirinya;

2. Kecakapan untuk membuat suatu perikatan;

3. Suatu hal tertentu;dan

4. Suatu sebab yang halal. 
dokter. ${ }^{9}$ Unsur yang biasanya terdapat dalam perbuatan melawan hukum di sini ialah adanya tindakan ketidakhati-hatian yang dilakukan oleh tenaga medis.

Dalam hal ini berlaku ketentuan UU No. 36 Tahun 2009 tentang Kesehatan Pasal 58 mengenai ganti rugi akibat adanya kesalahan atau kelalaian dalam pelayanan kesehatan yang diterima. Begitu pula jika dikaitkan dengan ketentuan 1365 BW bahwa untuk dapat disebut perbuatan melanggar hukum harus dipenuhi 4 (empat) syarat, yaitu :

a. Pasien harus mengalami suatu kerugian.

Pengganti kerugian karena perbuatan melawan hukum tidak diatur oleh undang-undang. Kerugian yang timbul dari perbuatan melawan hukum dapat merupakan kerugian harta keekayaan (material) tetapi dapat bersifat idiil (immaterial).

b. Ada kesalahan atau kelalaian (disamping perseorangan, rumah sakit juga bisa bertanggung jawab atas kesalahan atau kelalaian pegawainya).

Dalam hal ini kesalahan diartikan bahwa keadaan di mana seseorang dapat dipertanggungawabkan. Artinya perbuatannya dapat dipertanggungjawabkan namun karena ada keadaan memaksa maka tidak ada kesalahan. Kesalahan sendiri dari yang dirugikan ia dapat dibebani sebgaian dari kerugian itu, kecuali apabila perbuatan melawan hukum dilakukan sengaja, maka pembebanan sebagian dari kerugian kepada yang dirugikan itu adalah tidak beralasan.

c. Ada hubungan kausal antara kerugian dan kesalahan.

Untuk menentukan luasnya kerugian yang harus diganti maka dengan menilai kerugian rsebut. Dengan demikian seorang yang dirugikan harus sedapat mungkin ditempatkan dalam keadaan seperti kedaan jika tidak terjadi perbuatan melawan hukum. Jadi pihak yang dirugan berhak menuntut ganti rugi, tidak hanya kerugian yang telah ia derita pada waktu yang akan datang.

d. Perbuatan itu melanggar hukum.

Perbuatan melanggar hukumtersebut harus melanggar hak subyektif ranglain atau bertentangan dengan kewajiban hukum dar pembuat sendiri, yang telah diatur dalam undang-undang atau dengan kata lain melawan hukum ditafsirkan sebagai melawan undang-undang.

9 Moh. Hatta, Op.cit., hlm. 89. 
Pada perbuatan melawan hukum biasanya para pihak (pasien dan dokter) baru pertama kali betemu. Berbeda halnya dengan gugatan wanprestasi yang memerlukan suatu perikatan/perjanjian. Akan tetapi bukan tidak mungkin apabila kedua belah pihak telah mengadakan perjanjian dan kemudian timbul kecelakaan lalu mereka tidak hanya dapat menuntut atas tindakan wanprestasi, namun bisa sekaligus ditemukan unsur perbuatan melawan hukum.

Sebagai contoh, seorang dokter dalam melakukan operasi spataderen membuat pasien setelah dioperasi hanya dapat menggunakan kakinya secara terbatas karena kesalahan medik yang dilakukan oleh dokter. Dalam hal ini tidak hanya norma yang diperjanjikan yang dilanggar, tetapi telah terjadi pelanggaran terhadap norma umum yang berlaku di dalam masyarakat. Norma umum yang dimaksud adalah di mana sebagai sesama manusia harus saling memperlakukan sesamanya dengan saling hati-hati dan tidak boleh saling melukai atauapun menyakiti.

Pada prinsipnya dalam gugatan wanprestasi, unsur kesalahan tidak berdiri sendiri. Tidak demikian dalam gugatan perbuatan melawan hukum unsur kesalahan itu berdiri sendiri (scukd zelfstanding vereiste). Gugatan yang didasarkan pada perbuatan melawan hukum tindakan/perbuatan dokter harus dapat dipertanggungjawabkan dan dipersalahkan menurut hukum.

Dengan demikian, dalam menentukan suatu tindakan malpraktik medis yang dilakukan oleh dokter merupakan suatu perbuatan melawan hukum maka ukuran yang dipergunakan adalah kesalahan bukan lagi bersifat individualistis tetapi seorang dokter. Dalam artian kondisi seorang dokter yang dianggap mempunyai kemampuan sesuai akal sehat sehingga unsur kesalahan yang terdapat dalam gugatan perbuatan melawan hukum dalam kenyataannya sangat kecil.

\section{Pertanggungjawaban Dokter Dalam Tindakan Malpraktik Medis Dilihat dari Perspektif Hukum Perdata}

Menurut hukum, setiap pertanggungjawaban harus mempunyai dasar, yaitu hal yang menyebabkan timbulnya hak hukum seorang untuk menuntut orang lain sekaligus berupa hal yang melahirkan kewajiban hukum orang lain itu untuk 
memberi pertanggungjawabannya. ${ }^{10}$ Sehubungan dengan pertanggungjawaban hukum tersebut maka tanggung jawab di sini ialah tanggung jawab dokter dalam kaitan dengan tugas profesinya. Dari adanya tanggung jawab tersebut maka akan timbul konsekuensi di satu pihak. Dengan adanya tanggung jawab yang berat maka seorang profesional akan berusaha menghormati profesinya. Di sisi lain ada anggapan bahwa untuk memperkecil risiko dan tanggung jawabnya, para dokter menjadi ragu-ragu atau khawatir dalam menjalankan tugasnya. Hal ini karena para dokter melihat dengan adanya kesalahan dalam menjalankan profesi maka akan timbul akibat hukum berupa pertanggungjawaban dari dokter.

Dalam proses gugatan perdata, dapat dipastikan pertanggungjawaban dokter terhadap pasien hampir semuanya menyangkut tuntutan ganti rugi. Untuk gugatan yang berdasar atas wanprestasi lebih disebabkan dari adanya suatu perjanjian (tanggung jawab kontraktual) antara para pihak. Sedangkan, gugatan yang berdasarkan atas perbuatan melawan hukum disebabkan oleh tindakan dokter yang bertentangan dengan asas kepatutan, ketelitian dan sikap hati-hati yang diharapkan dari padanya dalam pergaulannya dengan sesama warga masyarakat (tanggung jawab berdasar undang-undang).

Berdasarkan undang-undang, hubungan antara tenaga kesehatan mengacu kepada Pasal 1365 BW, Pasal 1366 BW, dan Pasal 1367 BW. Pasal 1365 BW mengatur tentang perbuatan melawan hukum yang menyatakan, "Setiap perbutan yang melanggar hukum sehingga membawa kerugian kepada orang lain maka si pelaku yang menyebabkan kerugian tersebut berkewajiban untuk menuntut mengganti kerugian tersebut". Pasien dapat menggugat seorang dokter oleh karena dokter tersebut telah melakukan perbuatan melanggar hukum. Untuk menentukan seorang dokter bertanggung jawab dan melakukan ganti rugi, haruslah terdapat hubungan yang erat antara kesalahan dan kerugian yang ditimbulkan.

Pasal 1366 BW, seseorang tidak saja bertanggung jawab terhadap kerugian yang ditimbulkan oleh dirinya sendiri, tetapi juga bertanggung jawab terhadap tindakan dari orang-orang yang berada di bawah tanggung jawabnya atau disebabkan oleh barang-barang yang berada di bawah pegawasannya.

10 Venny Sulistyani, Zulhasmar Syamsu, "Pertanggungjawaban Perdata Seorang Dokter Dalam Kasus Malpraktik Medis," Lex Jurnalica, Vol. 12 No. 2 Tahun 2015, hlm. 149. 
Pasal 1367 BW digunakan untuk pertanggungjawaban dokter bagi orangorang yang berada di bawah pengawasannya. Lengkapnya seseorang tidak saja bertanggung jawab terhadap kerugian yang ditimbulkan oleh dirinya sendiri, tetapi juga bertanggung jawab terhadap tindakan dari orang-orang yang berada di bawah tanggung jawabnya atau disebabkan oleh barang-baerang yang berada di bawah pengawasannya. Sehubungan dengan ini seorang dokter harus bertanggung jawab atas tindakan yang dilakukan oleh bawahannya yaitu perawat, bidan, dan sebagainya. Kesalahan seorang perawat karena menjalankan perintah dokter adalah tanggung jawab dokter.

Perbuatan melawan hukum seperti yang telah dibahas di atas menggambarkan bahwa tangung jawab karena adanya kesalahan dari subyek hukum menimbulkan kerugian bagi pihak lain. Dari kesalahan yang merugikan pihak lain tersebut, maka timbul pertanggungjawaban dari subyek hukum yang bersangkutan atas kesalahannya sehingga ia harus mengganti kerugian yang ditimbulkan perbuatannya. ${ }^{11}$

Adapun hakikatnya tanggung jawab dokter dalam pelayanan medik secara umum ialah : ${ }^{12}$

a. Pertanggungjawaban karena kesalahan. Dalam pengertian perbuatan melawan hukum, perbuatan itu dapat dipersalahkan dan perbuatannya yang tidak hatihati itu seyogyanya dapat dihindari oleh pelaku. Pertanggungjawaban karena kesalahan adalah suatu bentuk klasik pertanggungjawaban yang didasarkan atas 3 (tiga) masalah mendasar, yaitu:

1) Setiap tindakan yang mengakibatkan kerugian atas diri orang lain menyebabkan orang yang melakukan harus membayar kompensasi sebagai pertanggungjawaban kerugian. (Pasal 1365 BW);

2) Seseorang harus bertanggung jawab tidak hanya kerugian yang dilakukan sengaja tetapi juga karena kelalaian atau kurang hati-hati. (Pasal 1366 BW); dan

11 Rini Dameria, Achmad Busro dan Dewi Hendrawati, "Perbuatan Melawan Hukum Dalam Tindakan Medis dan Penyelesaiannya di Mahkamah Agung (Studi Kasus Perkara Putusan Mahkamah Agung Nomor 352/PK/PDT/2010)," Diponegoro Law Journal, Vol. 6 No. 1 Tahun 2017, hlm. 7.

12 Moh. Hatta, Op.cit., hlm. 135. 
3) Seseorang harus bertanggung jawab tidak hanya atas kerugian yang dilakukannya sendiri, tetapi juga karena tindakan orang lain yang berada di bawah pengawasannya. (Pasal $1367 \mathrm{BW}$ ).

Aspek negatif dari bentuk pertanggungjawaban ini secara umum pasien harus membuktikan akan kerugian yang dideritanya. Ada kalanya sulit bagi pihak pasien (penggugat) untuk membuktikan adanya suatu kegagalan pemenuhan standar perawatan yang harus pertama-tama ditunjukkannya dalam pembuktian atas kerugian yang timbul. Lagi pula apabila perikatan itu menyangkut perikatan usaha (inspanning) maka sulit untuk membuktikan kesalahan atau kelalaian karena usaha yang tidak optimal, kebanyakan penggugat tidak memiliki cukup bukti untuk itu.

b. Pertanggungjawaban akan risiko.

Merupakan kebalikan dari pertanggungjawaban karena kesalahan. Dalam pertangggungjawaban karena risiko, pasien hanya perlu menunjukkan hubungan antara orang yang mengakibatkan kerugian dan kerugian yang dideritanya. Kebanyakan berkaitan dengan produk tertentu seperti obat, alatalat medik, dan sejenisnya. Untuk dapat menentukan seorang pelaku perbuatan melanggar hukum harus membayar ganti rugi, maka harus terdapat hubungan antara kesalahan dengan kerugian yang ditimbulkan. Dalam menentukan hal ini, terdapat 2 (dua) ajaran, yaitu: ${ }^{13}$

1) Teori condition sine qua non oleh Von Buri. Dalam teori ini mengajarkan bahwa pada setiap masalah, tanpa mana peristiwa tidak akan terjadi, untuk menentukan suatu hal sebagai suatu akibat adalah apabila seandainya hal itu tidak ada, maka kerugian tidak akan timbul. Dari teori ini maka pertanggungjawaban menurut Pasal 1365 BW diperluas karena perbuatan-perbuatan yang jauh hubungannya dengan akibatnya harus dianggap juga menjadi sebab, sehingga terjadi mata rantai fakta kausal yang menimbulkan suatu akibat tertentu. Di dalam praktik pembuktian adanya hubungan kausal antara perbuatan dan kerugian, tidak dapat dilakukan dengan sempurna, tetapi dapat disimpulkan sebagai "The most possible cause (sebab yang paling memungkinkan)".

13 Ibid., hlm. 211. 
2) Teori Adequate veroorzaking, sebab musabab yang bersifat adequate: dikembangkan oleh Von Kris yang mempunyai pengertian sebagai berikut:

a) Suatu kerugian hanya merupakan akibat dari perbuatan melawan hukum kalau kerugian tersebut menurut akal sehat manusia dapat diharapkan merupakan suatu akibat dari perbuatan melanggar hukum tersebut.

b) Kerugian tersebut merupakan akibat dari perbuatan melanggar hukum yang diduga semula.

c) Kerugian tersebut menurut pengalaman dapat diharapkan merupakan akibat perbuatan melawan hukum.

Pasal 1365 BW menentukan bahwa setiap setiap orang yang melakukan perbuatan melawan hukum serta menimbulkan kerugian harus mengganti kerugian tersebut. Kerugian yang timbul dari perbuatan melawan hukum dapat berupa ganti rugi baik secara materi ataupun immateri atau bisa pula kombinasi keduanya. Berbeda halnya dengan ganti rugi dalam gugatan wanprestasi yang hanya menuntut ganti rugi berupa materi. Adapun bentuk ganti rugi yang dikenal dalam hukum perdata, yakni: ${ }^{14}$

a. Ganti rugi umum, yaitu yang berlaku untuk semua kasus termasuk karena perbuatan melawan hukum. Adapun ketentuan ganti rugi secara umum ini oleh BW diatur dalam Pasal 1243 - Pasal 1252 BW yang dapat berupa biaya ganti rugi serta bunga.

b. Ganti rugi khusus, yaitu ganti rugi yang hanya timbul dari perikatan-perikatan tertentu.

Setiap perbuatan malpraktik medis yang berkaitan dengan perbuatan melawan hukum dilakukan oleh dokter dapat dilakukan upaya penyelesaian sebagaimana yang terdapat dalam ketentuan hukum Perdata. Begitu juga jalur yang ditempuh baik melalui nonlitigasi, negosiasi dan mediasi maupun litigasi. ${ }^{15}$ Jalur litigasi merupakan jalur di dalam pengadilan (perdata) sebagaimana tertuang dalam UU

14 Munir Fuady, Sumpah Hippocrates (Aspek Hukum Malpraktik Dokter), Jakarta: PT. Citra Aditya Bakti, 2005, hlm. 134.

${ }_{15}$ Sri Siswati, Etika dan Hukum Kesehatan, Jakarta: PT RajaGrafindo Persada, 2015, hlm. 155. 
No. 29 Tahun 2004 tentang Praktik Kedokteran Pasal 66, (1) Setiap orang yang mengetahui atau kepentingannya dirugikan atas tindakan dokter atau dokter gigi dalam menjalankan praktik kedokteran dapat mengadukan secara tertulis kepada Ketua Majelis Kehormatan Disiplin Kedokteran Indonesia; (2) Pengaduan sekurang-kurangnya harus memuat identitas pengadu, nama, dan alamat tempat praktik dokter atau dokter gigi dan waktu tindakan dilakukan serta alasan pengaduan; (3) Pengaduan sebagaimana dimaksud pada ayat (1) dan ayat (2) tidak menghilangkan hak setiap orang untuk melaporkan adanya dugaan tindak pidana kepada pihak yang berwenang dan/atau menggugat kerugian perdata ke pengadilan.

\section{SIMPULAN}

Berdasarkan hasil pembahasan maka diperoleh kesimpulan sebagai berikut:

1. Gugatan perbuatan melawan hukum (onrechtmatigedaad) dalam tindakan malpraktik medis diatur dalam Pasal 1365 BW yang berbunyi, "Tiap perbuatan melawan hukum, yang membawa kerugian kepada orang lain, mewajibkan orang yang karena salahnya menerbitkan kerugian itu, mengganti kerugian tersebut". Perbuatan melawan hukum diartikan bahwa salah satu pihak telah melakukan perbuatan melawan hukum karena tindakannya atau perbuatannya bertentangan dengan asas kepatutan, ketelitian serta sikap kehati-hatian terutama dalam hal ini perjanjian atau kesepakatan antara pasien dengan dokter. Untuk dapat disebut perbuatan melanggar hukum harus dipenuhi 4 (empat) syarat, yaitu : 1) Pasien harus mengalami suatu kerugian; 2) Ada kesalahan atau kelalaian (disamping perseorangan, rumah sakit juga bisa bertanggung jawab atas kesalahan atau kelalaian pegawainya); 3) Ada hubungan kausal antara kerugian dan kesalahan; 4) Perbuatan itu melanggar hukum. Dalam gugatan perbuatan melawan hukum unsur kesalahan itu berdiri sendiri (scukd zelfstanding vereiste). Artinya gugatan pada perbuatan melawan hukum tindakan/perbuatan dokter tersebut harus dapat dipertanggungjawabkan dan dipersalahkan menurut hukum.

2. Pertanggungjawaban dokter atas perbuatan melawan hukum tindakan malpraktik medis berdasarkan undang-undang mengacu kepada Pasal 1365 BW, Pasal 1366 BW, dan Pasal 1367 BW. Pasal 1365 BW diartikan bahwa pasien dapat menggugat seorang dokter oleh karena dokter tersebut telah 
melakukan perbuatan melanggar hukum. Dengan demikian untuk menentukan seorang dokter bertanggung jawab dan memberikan ganti rugi, haruslah terdapat hubungan yang erat antara kesalahan dan kerugian yang ditimbulkan. Kemudian Pasal 1366 BW menjelaskan bahwa, seseorang tidak saja bertanggung jawab terhadap kerugian yang ditimbulkan oleh dirinya sendiri, tetapi juga bertanggung jawab terhadap tindakan dari orang-orang yang berada di bawah tanggung jawabnya atau disebabkan oleh barangbarang yang berada di bawah pegawasannya. Pasal 1367 BW digunakan untuk pertanggungjawaban dokter bagi orang-orang yang berada di bawah pengawasannya. Dengan demikian seorang dokter harus bertanggung jawab atas tindakan yang dilakukan oleh bawahannya yaitu perawat, bidan, dan sebagainya, sehingga kesalahan seorang perawat karena menjalankan perintah dokter adalah tanggung jawab dokter.

\section{DAFTAR PUSTAKA}

\section{Buku:}

A. Garner, Bryan. 2006. Black’s Law Dictionary, Thomson West

Fuady, Munir. 2005. Sumpah Hippocrates (Aspek Hukum Malpraktek Dokter), Jakarta: PT. Citra Aditya Bakti

Hatta, Moh. 2013. Hukum Kesehatan dan Sengketa Medik, Yogyakarta: Liberty

Indriyanti Dewi, Alexandra. 2008. Etika dan Hukum Kesehatan, Yogyakarta: Pustaka Book Publisher

Siswati, Sri. 2015. Etika dan Hukum Kesehatan, Jakarta: PT RajaGrafindo Persada

\section{Jurnal:}

Andi Fitriono, Riska, Budi Setyanto dan Rehnalemken Ginting, "Penegakan Hukum Malpraktik Melalui Pendekatan Mediasi Penal," Yustisia, Vol. 5 No. 12016 
Dameria, Rini, Achmad Busro dan Dewi Hendrawati, "Perbuatan Melawan Hukum Dalam Tindakan Medis dan Penyelesaiannya di Mahkamah Agung (Studi Kasus Perkara Putusan Mahkamah Agung Nomor 352/PK/PDT/2010)," Diponegoro Law Journal, Vol. 6, No. 12017

I Gusti Ayu Apsari Hadi, "Pertanggungjawaban Pejabat Pemerintahan Dalam Tindakan Diskresi Pasca Berlakunya Undang-Undang No. 30 Tahun 2014 Tentang Administrasi Pemerintahan,” Kertha Patrika, Vol. 39 No.1 2017

Venny Sulistyani, Zulhasmar Syamsu, "Pertanggungjawaban Perdata Seorang Dokter Dalam Kasus Malpraktik Medis,” Lex Jurnalica, Vol. 12 No. 22015

\section{Peraturan Perundang-Undangan :}

R. Subekti \& R. Tjitrosudibio, Kitab Undang-Undang Hukum Perdata

Undang-Undang No. 29 Tahun 2004 tentang Praktik Kedokteran

Undang-Undang No. 36 Tahun 2009 tentang Kesehatan 